\title{
Müdür Yardımcılarının İş Doyumunun Yordayıcısı Olarak Okul Müdürlerinin Mentorluk Fonksiyonları ${ }^{1}$
}

\author{
Uğur ÖZALP*
}

Haydar Akçelik Meslekî ve Teknik Anadolu Lisesi, Eyüp / İstanbul / Türkiye

\section{Yrd. Doç. Dr. Ramazan YİRCí}

Kahramanmaraş Sütçü İmam Üniversitesi, Eğitim Fakültesi, Avşar / Kahramanmaraş / Türkiye

\section{Doç. Dr. İbrahim KOCABAŞ}

Yıldız Teknik Üniversitesi, Eğitim Fakültesi, Dvautpaşa Kampüsü, İstanbul / Türkiye

\section{$\ddot{O} z$}

$\mathrm{Bu}$ çalışmanın amacı, okul müdürlerinin sergilediği mentorluk fonksiyonlarının müdür yardımcılarının iş doyumuna ulaşma düzeyinin yordayıcısı olup olmadığını incelemektir. Veri toplama aracında, "Mentorluk Fonksiyonları Ölçeği” ve "Minnesota Doyum Ölçeği” yer almaktadır. Araştırmada ilişkisel tarama modeli kullanılmıştır. Araştırmanın örneklemini kolayda örnekleme yöntemiyle belirlenen

\footnotetext{
${ }^{1}$ Bu makale, 2016 yılında İstanbul Aydın Üniversitesi ve Yıldız Teknik Üniversitesi Sosyal Bilimler Enstitüleri’nin ortak yürüttüğü Eğitim Yönetimi ve Denetimi Yüksek Lisans Programı'nda Uğur ÖZALP tarafindan hazırlanan “Okul Müdürlerinin Mentorluk Fonksiyonlarının Okul Müdür Yardımcılarının İş Doyumuna Etkisi” başlıklı yüksek lisans tezinden üretilmiştir.

* Sorumlu Yazar.

Tel: +905056782682

E-posta: ozalp.ugur@ hotmail.com

(C) 2016 Kalem Eğitim ve Sağlık Hizmetleri Vakfı. Bütün Hakları Saklıdır. ISSN: 2146-5606
} 
2015-2016 eğitim-öğretim yılında Bakırköy, Eyüp, Gaziosmanpaşa ve Kâğıthane ilçelerindeki Millî Eğitim Bakanlığına bağlı okullarda görev yapmakta olan 611 müdür yardımcısı oluşturmaktadır. Ölçekler, internet ortamında sunularak veri toplama işlemi gerçekleştirilmiştir. Ölçeklere ilişkin link, belirtilen ilçelerde yer alan okulların resmî e-posta adreslerine gönderilmiştir. Ölçeğe 402 kişi cevap vermiş, katılım oran $1 \% 65.8$ olarak tespit edilmiştir. Elde edilen veriler IBM SPSS Statistics (v22) ve MPlus (v7) programları vasıtasıyla çözümlenmiş ve değerlendirilmiştir. Ölçeklerden elde edilen puanlara yönelik frekans dağılımı, yüzde oranı, aritmetik ortalama ve standart sapma hesaplanmıştır. Verilerin analizinde basit doğrusal korelasyon analizi ve basit doğrusal regresyon analizi yöntemleri kullanılmıştır. Çalışmada, hata payı .05 olarak kabul edilmiştir. Araştırma sonuçlarına göre müdür yardımcılarının iş doyumu ile okul müdürlerinin sergilediği mentorluk fonksiyonları arasında orta düzeyde, pozitif yönde ve anlamlı düzeyde bir ilişki vardır. Müdür yardımcılarının deneyimlediği iş doyumu düzeyinin okul müdürlerinin sergiledikleri mentorluk fonksiyonları ile doğru orantılı bir biçimde artış gösterdiği belirlenmiştir. Mentorluk fonksiyonlarının iş doyumunun yordayıcısı olduğu tespit edilmiştir.

Anahtar Kelimeler: Mentor; Menti; Mentorluk fonksiyonları; İş doyumu; Okul müdürü; Müdür yardımcısı.

\title{
Mentoring Functions of School Principals as Predictor of the Level of Job Satisfaction of Assistant Principals
}

\begin{abstract}
The purpose of the study was to examine if the level of mentoring functions the school principals perform is a predictor of the level of job satisfaction assistant principals experience. The survey instrument used for this research included "Mentoring Functions Scale" and "Minnesota Satisfaction Questionnaire". Relational screening model was used in the study. Universe of the study is comprised of the 611 assistant principals who work in schools affiliated to Ministry of National Education in Bakırköy, Eyüp, Gaziosmanpaşa and Kâğıthane districts of İstanbul province. The scale was used in the web based survey to collect data. Data was collected by sending the web based survey link to the formal e-mail addresses of the schools in the mentioned districts. There were total 402 respondents giving a $65.8 \%$ response rate. The
\end{abstract}


obtained data was analyzed and evaluated using IBM SPSS Statistics (v22) and MPlus (v7). Frequency and percentage distributions, mean and standard deviations were calculated. Simple linear correlation analysis and simple linear regression analysis were performed. The error margin for the study was .05. According to the results, there is a moderate, positive and significant relationship between the job satisfaction of assistant principals and the level of mentoring functions the principals perform. It is confirmed that the level of job satisfaction the assistant principals experience increase in direct proportion with the level of mentoring functions the school principals perform. Mentoring is found to be predicator of job satisfaction.

Keywords: Mentor; Mentee; Mentoring functions; Job satisfaction; School principal; Assistant principal.

\section{Extended Summary}

It is essential for schools to have qualified employees in order to achieve success and maintain sustainability. Hence, it holds importance to train the school employees and guide them (Kocabaş and Yirci, 2011). At this point, the term "mentor" confronts. Having roots in Greek mythology, mentoring became an important term in the workplace environment of the $21^{\text {st }}$ century (Cakir and Kocabaş, 2016; Kahle-Piasecki, 2011). According to Bakioğlu and Hacifazlioğlu (2013), mentor is an experienced person in the job field who provides support and gives advice to the newly recruited, inexperienced employee. Mentoring is one of the basic forms of individual development in which a person invests time, energy and personal experience for development of another individual. Mentor is an individual who brings knowledge, understanding, perspective and wisdom to another person. By the help of mentoring, individual who benefits the mentoring relationship advances both in career and psychosocial aspects (Kram, 1983; Shea, 2002).

Mentoring, with its career and psychosocial functions, intervened in our lives in 1980's after it is confirmed that it enhances professional success, personal development, leadership development and organizational productivity. Subjective outcomes of mentoring including perceived career success, organizational justice, job satisfaction, organizational commitment and organizational power became the focus of mentoring research (Borredon and Ingham, 2004; Dougherty and Dreher, 2007). Among these focal points, this research inspects the job satisfaction. 
According to Keser (2005), the term job satisfaction delineates the state of being pleased or unpleased originating from the job done. Aziri (2011) states that an employee experiencing job satisfaction is a happy employee and a happy employee is a successful employee. In this respect, having talented and dedicated employees provide advantage to the organizations in terms of competition (Holtom, Mitchell, Lee and Eberly, 2008; Pfeffer, 1994).

Ereş (2009) puts forward that school administrators do not receive education on administration and try to advance by trial-and-error without theoretical knowledge. Mentoring gains importance on putting the theoretical knowledge into practice. From this point of view, mentoring of school principals in training the assistant principals is an inevitable necessity and most of the time it occurs by itself instead of preplanned programs (Calabrese and Tucker-Ladd, 1991; Paskey, 1989).

\section{Purpose}

It is considered that mentoring functions of school principals is important in easing the assistant principals, who are responsible for the jobs to reach the organizational goals, in achieving job satisfaction. In this context, it is expected to contribute to the education field by examining the level of prediction of mentoring functions of school principals on job satisfaction of assistant principals. The purpose of the study is to examine if the level of mentoring functions the school principals perform is a predictor of the level of job satisfaction assistant principals experience.

\section{Method}

Relational screening model was used in the study. Universe of the study is comprised of the 611 assistant principals who work in schools affiliated to Ministry of National Education in Bakırköy, Eyüp, Gaziosmanpaşa and Kâğıthane districts of İstanbul province. The scale was used in the web based survey to collect data. Data was collected by sending the web based survey link to the formal e-mail addresses of the schools in the mentioned districts. There were total 402 respondents giving a $65.8 \%$ response rate.

According to Dougherty and Dreher (2007), Noe (1988) developed the most frequently used scale for mentoring functions which aims to evaluate career and psychosocial functions. "Mentoring Functions Scale" which has 
29 items was used in the survey instrument by permission of the author. Exploratory (EFA) and confirmatory analysis (CFA) were conducted for construct validity. EFA resulted in single factor structure which explains $72.70 \%$ of the total variance. CFA confirmed the single factor structure $\left(\chi^{2} / \mathrm{sd}=3.03, \mathrm{TLI}=0.94, \mathrm{CFI}=0.95, \mathrm{SRMR}=0.02, \mathrm{RMSEA}=0.07\right)$. The obtained single factor model is in agreement with the one found by Şerefhanoğlu (2014). The Cronbach's Alpha reliability co-efficient was found .98 which shows high reliability.

The most commonly used scale for measuring the level of job satisfaction is "Minnesota Satisfaction Questionnaire" (Aziri, 2011; Judge, Parker, Colbert, Heller and Ilies, 2001; Spector, 1997). The scale was developed by Weiss, David, England and Lofquist (1967). 1977 version of short form of the scale was used in the survey instrument by permission of the authors. EFA and CFA were conducted to construct validity. EFA resulted in single factor structure which explains $50.16 \%$ of the total variance. CFA confirmed the single factor structure $\left(\chi^{2} / \mathrm{df}=2.33\right.$, TLI $=0.95, \mathrm{CFI}=0.96, \mathrm{SRMR}=0.03$, RMSEA=0.05). The obtained single factor model is in agreement with the one found by Kul (2010). The Cronbach's Alpha reliability co-efficient was found .94 which shows high reliability.

\section{Results}

In order to determine correlation between the job satisfaction level of assistant principals and mentoring functions of school principals, simple linear correlation analysis was conducted. Results showed that there is a moderate, positive and significant relationship between the job satisfaction of assistant principals and the level of mentoring functions the principals perform $(\mathrm{r}=.58, p=.000<.05)$.

Simple linear regression analysis was conducted so as to reveal if mentoring functions of school principals is a predictor of job satisfaction of assistant principals. It is confirmed that mentoring functions of school principals is a significant predictor of the job satisfaction of assistant principals $\left(\mathrm{R}=0.583, \mathrm{R}^{2}=0.340, \mathrm{~F}_{(1,400)}=205.93, p=.000<.05\right)$. The equation predicting job satisfaction of assistant principals is as follows:

Job Satisfaction $=(0.383 *$ Mentoring $)+2.434$ 


\section{Discussion and Conclusion}

It was found that the mentoring functions of school principals is a statistically significant predictor of job satisfaction of the assistant principals. There is a moderate, positive and significant relationship between the job satisfaction of assistant principals and the level of mentoring functions the principals perform. These results are in phase with the findings of Karakus and Tok (2015), Allen, Eby, Poteet, Lentz and Lima (2004), Anderson (2010), Appelbaum, Ritchie and Shapiro (1994), Kennedy (2013), Kim (2011) and Morrison (2009).

According to the findings of this research, school principals should put mentoring functions foreground in their relationships with the assistant principals. Besides, there is no formal mentoring program targeting school principals or assistant principals in Turkey. Formal mentoring programs should be prepared in order to help the assistant principals experience more job satisfaction and contribute the schools in achieving their goals in this way.

\section{Giriş}

Okulların amaçlarına ulaşarak başarılı olmaları ve sürekliliklerini devam ettirmeleri bakımından nitelikli çalışanlarının olması esastır. Dolayısıyla, okul çalışanlarının yetiştirilmesi, çalışanlara rehberlik edilmesi önem taşımaktadır (Kocabaş ve Yirci, 2011). Bu noktada, "mentor" kavramı karşımıza çıkmaktadır. Kökleri Yunan mitolojisine kadar uzanan mentorluk, küresel rekabete ve teknoloji kullanımının yaygınlaşmasına bağlı olarak değişen koşullar çerçevesinde 21. yüzyılın iş ortamında önemli bir kavram hâline gelmiştir (Kahle-Piasecki, 2011). Bakioğlu ve Hacıfazlığlu'na (2013) göre mentor, mesleğe yeni başlamış, deneyimsiz bireye destek sağlayan, tavsiye veren, meslekte 10-15 y1l daha deneyimli bireydir. Mentorluk, kişinin başka birisinin gelişimine yardımcı olmak amacıyla zaman, enerji ve kişisel birikimiyle yatırım yaptı̆̆ 1 , insan gelişiminin temel biçimlerinden biridir. Mentor, başka birine bilgi, anlayış, bakış açısı ya da bilgelik kazandıran kişidir. Mentorluk sayesinde hem mentor hem de mentorluk hizmetinden faydalanan birey (menti) kariyer ve psikososyal bakımdan ilerleme kaydeder (Kram, 1983; Shea, 2002). 
Meslekî başarıyı, kişisel gelişimi, liderlik gelişimini ve örgütsel üretkenliği arttırdığının tespit edilmesini takiben, kariyer ve psikososyal işlevleriyle mentorluk, 1980 'lerde ortaya çıkan yeni yönetim anlayışıyla birlikte hayatımıza girmiştir. Araştırmacıların, kariyer başarısının nesnel getirilerden daha fazlasını içerisinde barındırdığını keşfetmesinin ardından, algılanan kariyer başarısı, kariyer beklentisi, örgütsel adalet, işi benimseme, iş doyumu, örgütsel adanmışlık, tükenmişlik ve örgütsel güç de dâhil olmak üzere mentorluğun öznel getirileri, mentorluk çalışmalarının odağını oluşturmaya başlamıştır (Borredon ve Ingham, 2004; Dougherty ve Dreher, 2007). Bu araştırma, mentorluk çalışmalarının odağında yer almaya başlayan, mentorluk ve iş doyumu ilişkisini incelemektedir.

Keser'e (2005) göre, iş doyumu kavramı, iş görenlerin yaptıkları işten kaynaklı hoşnutluk ya da hoşnutsuzluk durumunu tarif etmektedir. Aziri (2011), iş doyumuna ulaşmış çalışanın mutlu bir çalışan olacağını ve mutlu bir çalışanın da başarılı bir çalışan olacağını belirtmektedir. Bu bakımdan, kabiliyetli ve adanmış çalışanlara sahip olmak, örgütlere rekabet açısından avantaj sağlar (Holtom, Mitchell, Lee ve Eberly, 2008; Pfeffer, 1994). Burke ve Richardsen (2001), iş doyumunun, iş arkadaşları ve yöneticiler, otonomi, kontrol, terfi, ücret gibi işin çeşitli boyutlarıyla ilişkisi üzerine çalışmalar yapılmış bir konu olduğunu ifade etmektedir.

Recepoğlu ve Kılınç (2014), okul yöneticiliğinin ülkemizde meslekleşemediğini, buna bağlı olarak da okul yöneticilerinin yetiştirilmesinde kişilerin herhangi bir eğitim sürecine tâbi tutulmadığını ifade etmektedir. Ereş (2009), okul yöneticilerinin eğitim yönetimi konusunda eğitim almaks1zın görev yaptıklarına ve kuramsal bilgiden yoksun bir biçimde deneme yanılma yoluyla ilerlemeye çalıştıklarına dikkat çekmektedir. Edinilen teorik bilginin uygulamaya geçirilmesi noktasında mentorluk süreci önem kazanmaktadır. Bu bakımdan, okul müdürlerinin, okul yönetimi sürecinin her aşamasında omuz omuza çalıştıkları müdür yardımcılarının yetiştirilmesinde mentorluk yapmaları karşı konulamaz bir zorunluluktur ve bu durum genellikle önceden tasarlanmış programlar yoluyla değil, kendiliğinden ortaya çıkar (Calabrese ve Tucker-Ladd, 1991; Paskey, 1989).

İçerisinde yer aldığ toplumun değerlerini, yaşam felsefesini paylaşan ve toplumun hedeflerini yerine getirme potansiyeline sahip bireyler yetiştir- 
mek, eğitim örgütleri olan okulların temel görevlerindendir. Okulların bu görevleri yerine getirebilmesi noktasında okul yöneticileri, okul yöneticileri arasında yer alan müdür yardımcılarının yetiştirilmesi sürecinde de okul müdürleri önem taşımaktadır. Mentorluk süreci sayesinde okul yöneticileri bilgi bakımından donanım kazanmanın yanında örgütsel amaçlara ilişkin duygusal açıdan da hazırlanmış olacaktır (Ereş, 2009; Sezgin, Koşar ve Er, 2014). Müdür yardımcıları, mentorluk sayesinde deneyimli okul müdürlerinin gözetiminde işin can alıcı noktalarını daha kolay bir biçimde öğrenmekte, karşılaştıkları zorlukların kolay bir biçimde üstesinden gelebilmektedir (Yirci ve Kocabaş, 2012).

17 Nisan 2015 tarihinde Resmî Gazete'de yayınlanarak yürürlüğe giren Millî Eğitim Bakanlığı Öğretmen Atama ve Yer Değiştirme Yönetmeliğinin (MEB, 2015) 54. maddesi, her tür ve derecedeki okul müdürlerine, ikinci görev olarak müdür yardımcılığı yapanlar da dâhil olmak üzere adaylık sürecini tamamlamış olan tüm öğretmenleri değerlendirme yetkisi vermektedir. Böylelikle öğretmenlere rehberlik etme bakımından yeterli uzmanlık bilgisine sahip olmaları beklenen (Korkmaz, 2005) okul müdürlerine örgütsel etkililiğe ilişkin vazgeçilmez bir süreç olan, bir rehberlik ve geliştirme süreci olarak görülen denetim (Yılmaz, 2009) konusunda resmî olarak yetki ve sorumluluk verilmiştir.

Okul müdürü, öğretmen, yönetici ve diğer personeli etkili bir biçimde yönetme, okul çevresiyle olumlu ilişkiler geliştirme, okulda paylaşılan etik değerleri belirleme ve okulun fizikî olanaklarını iyileştirme gibi sorumlulukların yanında öğretim lideri olarak sistem içerisinde yer almaktadır. Okul müdürleri, derin meslekî bilgi ve birikime sahip kişiler olarak görülmektedir (Balyer, 2012; Gürbüz, Erdem ve Yıldırım, 2013; Karaköse ve Kocabaş, 2009). Mevzuatla okul müdürlerine verilen rehberlik etme, denetleme ve geri bildirimde bulunma görevi, okul müdürlerini mentor olarak konumlandırmaktadır.

\section{Mentor ve Mentorluk Kavramları}

Mentorluğun tarihi, kabilenin yaşlı üyelerinin gençlere nasıl avlanılacağını, nasıl yiyecek toplanacağını ve düşmanlara karşı nasıl savaşılacağını öğrettiği, seçilen genç üyelere, yetenekli mağara ressamları, şamanlar ve şifacılar tarafindan bu becerilerin devam ettirilmesi için eğitim verildiği taş 
devrine kadar uzanmaktadır (Stone, 2002). Her ne kadar, taş devrinden beri var olan mentorluğa yönelik akademik ilginin geçmişi çok eskilere gitmese de Homeros'un Odesa'sında karşımıza çıkan bilge ve sadık akıl hocası Mentor, mentorluğun ilk yazılı örneğini ortaya koymaktadır (Ragins ve Kram, 2007).

Toplumumuzun tarihine bakıldığında mentorluk kavramının Orta Asya'dan Anadolu'ya uzanan yolculuğumuzda bizimle birlikte seyahat ettiği görülmektedir. Farklı dönemlerde farklı isimlerle anılsa da mentorluk, toplumumuzun uzak olmadığı bir uygulamadır. Alayoğlu (2012), günümüzde adlandırıldığ 1 şekliyle mentorluğun yeni bir kavram gibi görünmesine karşın tarihî ve kültürel bakımdan toplumumuzda köklü bir geçmişe sahip olduğunu ifade etmektedir.

Tarihî kayıtlar göstermektedir ki dilimizde henüz Türkçe karşılık yerleşmemiş olsa da mentorluk sistemi Atabeglik, Lalalık ya da Ahilik olarak geçmişimizde yer almaktadır (Alayoğlu, 2012). Selçuklular döneminde şehzadelerin siyaset ve savaş işlerini öğrenmesini sağlamak amacıyla danışmanl1k ve rehberlik etmek üzere tecrübeli komutan ya da vezir gibi devlet adamları görevlendirilmiş ve kendilerine devlet nezdinde çok yüksek bir görevi ifade eden "atabeg" unvanı verilmiştir. Şehzadeler bir vilayetin yönetiminde görevlendirilmiş ve hem kuram hem de uygulama bağlamında atabeglerin mentorluğunda yetiştirilmiştir. Harzemşahlar'da "ulug ala beg" olarak adlandırılan bu kişiler Osmanlılar'da "lala" olarak isimlendirilmiştir. Yine Selçuklular zamanında ortaya çıkıp Osmanlı Devleti'nin ilk yüzyıllarında etkili olan "ahilik", küçük esnaf, usta, kalfa ve çırakların içerisinde yer ald1ğ1, dayanışma temelli, meslekî bilgilerin usta-çırak ilişkisi içerisinde aktarıldığı diğer bir mentorluk sistemidir (Akyüz, 2015).

Türk Dil Kurumu Büyük Türkçe Sözlüğünde (b.t.) "Herhangi bir iş yerinde farklı görevlerde çalışarak deneyim kazanmış olan, danışan kişinin hedefine ulaşmasını sağlayacak yolu bulmasına yardımcı kimse, yönder" olarak tanımlanan mentorluğun, alan araştırmacıları tarafından üzerinde fikir birliğine varılmış bir tanımı bulunmamaktadır. Buna karşın bütün mentorluk ilişkilerinin tüm çevrelerce kabul görmüş bazı anahtar özellikleri vardır. $\mathrm{Bu}$ özellikler, mentorluğu diğer kişiler arası ilişkilerden ayırmaktadır (Haggard, Dougherty, Turban ve Wilbanks, 2011). Mentorluk, isteğe bağlı olarak ya da 
profesyonel olarak icra edilen, başka bir bireyin gelişimine destek sağlamak için yargısız bir biçimde bire bir ilişki şeklinde hayata geçirilen bir eylemdir (Özkalp, Kırel, Sungur ve Cengiz, 2006). Kişinin bir aşamadan diğerine geçişine yardım etme biçimi olan mentorluğun açık bir amacı vardır: değişimi hedefleyerek bireyin öğrenmesini ve gelişmesini sağlamak. Her ne kadar ilk etapta yalnızca iş dünyasında yer aldığı düşünülse de mentorluk, insan etkinliklerinin tümünde karşımıza çıkmaktadır (Brockbank ve McGill, 2006; Sandybayev ve Erdem, 2015; Wallace ve Gravells, 2008).

Mentorluk ilişkilerini diğer kişisel ilişkilerden ayıran temel özellik, mentorluğun kişinin kariyeri bağlamı içerisinde yer alan gelişimsel bir ilişki olmasıdır. Farklı iş ya da kişisel ilişki neticesinde öğrenme, gelişme ve ilerleme ortaya çıkabilir. Ancak mentorluk ilişkilerini farklı kılan şey, bu ilişkilerin odağında kariyer ilerlemesi ve gelişimin bulunmasıdır (Ragins ve Kram, 2007).

\section{Mentorluk fonksiyonları}

Noe (1988) mentorluğun, temelde, kariyer fonksiyonu ve psikososyal fonksiyon olmak üzere iki fonksiyonu olduğunu ifade etmektedir. Mentinin iş doyumunda belirleyici olan her iki işlev de genel iş-yaşam dengesinin yanında, meslekî gelişim açısından da örtük ve açık çıkartımlar sunmaktadır (American Psychological Association, 2006; Ragins ve Kram, 2007).

Mentorluk ilişkileri, sağlanan mentorluk fonksiyonlarının derecesine göre çeşitlilik göstermektedir. Mentorluğu hep ya da hiç şeklinde özetlemek mümkün değildir. Mentinin beklentileri, mentorun bu beklentileri karş1layabilme derecesi, mentorun beklentileri, ilişkinin kimyası ve örgütsel bağlama göre farklılık gösterecek biçimde, mentor, sayılan fonksiyonların hepsini yerine getirebileceği gibi yalnızca belirli başlı olanlarını da yerine getirebilir (Ragins ve Cotton, 1999; Ragins ve Kram, 2007).

\section{Kariyer geliştirme fonksiyonu}

Kariyer geliştirme fonksiyonunun odağında örgüt ve mentinin kariyeri yer alır. Kariyere yönelik işlev, mentoru, mentinin meslekî performansı ve gelişimini ilerletmeye yönelik önerilerde bulunan koç olarak kabul etmektedir (APA, 2006). Bu fonksiyon, mentinin kariyer gelişimini destekleyen mentorluk davranışlarını içerir. Mentorun örgütteki pozisyonu ve gücüne göre değişiklik gösteren kariyer geliştirme fonksiyonları, mentinin işi öğ- 
renmesine yardımcı olur ve mentileri örgüt hiyerarşisi içerisinde yükselmeye hazırlar. Mentorluk araştırmaları, mentorluk sürecinde mentor tarafından sergilenen kariyer fonksiyonlarıyla mentinin maddî kazancı, doyumu ve terfisi arasında olumlu ilişki olduğuna dair destekleyici bulgular sunmaktadır. (Chao, 2007; Ragins ve Cotton, 1999; Ragins ve Kram, 2007).

\section{Destekleme}

Destekleme, arzulanan yatay hareket ve terfiye aday olacak k1demi düşük meslektaşın tespitidir. Mentinin terfi etmesi ve mentinin kariyer gelişimine katkı sunacak ödüller, araştırma projeleri, burslar gibi diğer firsatlar için önerilmesini kapsar. Örgütün yeni katılımcılarının itibar edinmelerine ve bilinir hâle gelmelerine yardımcı olur. Destekleme aynı zamanda mentinin terfi almasına ve arzulanan yönde ilerlemesine de yardımcı olur. Mentorun, menti adına terfi ve diğer yeni görevler için resmî ve gayrı resmî olarak görüş beyan etmesini de kapsar. Menti, itibar kazanır ve iş firsatları elde eder. Mentor, hüküm verme konusunda başarılı olduğu, yetenekli kişileri ortaya çıkartıp gelişimlerini temin etme konusunda başarılı olduğu şeklinde değerlendirilir. Ancak bu durum, mentinin sergilediği performansa bağlı olarak mentorun itibarını yükseltebileceği gibi itibarına zarar da verebilir (Dougherty, Turban ve Haggard, 2007; Educause, b.t.; Fagenson-Eland ve Lu, 2004; Greenhaus ve Singh, 2007).

\section{Koçluk}

Koçluk fonksiyonu, mentinin belirli bazı işle alakalı amaçlara ulaşmak, kabul görmek ve kariyer beklentilerini karşılamak için izleyeceği stratejilerin önerilmesini -ipucu vermeyi- içermektedir. Menti, örgüte yönelik bilgi sahibi olur, bakış açısını ve örgüt içerisinde hareket alanını genişletir. Bilgi aktarımı, mentorun tecrübesinin önem taşıdığının göstergesidir. Mentor, kendini etkin hissetmeye başlar (Dougherty, Turban ve Haggard, 2007; Educause, b.t.; Greenhaus ve Singh, 2007).

\section{Koruma}

Başarıya giden yolda birçok risk ve tehlike bulunmaktadır. Bunların bazıları apaçık ortadayken bazılarını görmek zordur. Bazen en yetenekli menti bile bu tehlikelere hazırlıksız yakalanabilir. Mentorlar, başarıya giden yoldan daha önce geçtiklerinden tehlike ve risklere dair işaretlere aşinadırlar 
ve mentilerini bu tehlikelere karşı korumaya hazır olmalıdırlar (Johnson ve Ridley, 2004).

\section{Meydan okuyucu görevler sağlama}

İyi mentorlar, hedef odaklıdır ve mentinin alanında yeni beceriler kazanmasını ve daha yüksek seviyelere ulaşmasını hedefler. Meydan okuyucu görevler sağlamak, mentinin, bir profesyonel olarak başarı elde etmede ihtiyacı olacak bilgi edinimi ve beceri gelişimine yardımcı olur. Gerekli teknik ve yönetimsel beceriler, iş üzerinde geliştirilir ve meydan okuyucu görevler yerine getirilirken ortaya çıkan öğrenme yoluyla desteklenir (Dougherty, Turban ve Haggard, 2007; Educause, b.t.; Fagenson-Eland ve Lu, 2004).

\section{Ortaya çıkarma ve görünür kılma}

Ortaya çıkarma ve görünür kılma ise mentinin gelişimine etki etmesi olası kıdemli meslektaşlarıyla, önemli hesaplar üzerine çalışmak, etkin komisyonlarda görev almak ya da etkin paydaşlarla irtibat hâlinde olmayı gerektiren projelerde yer almak gibi görevler yoluyla buluşmasını sağlamayı içermektedir. Mentinin üst düzey yöneticilerle irtibat kurmasını temin eden görevler sayesinde, menti, örgütün başka birimleri ve daha üst seviyelerdeki örgütsel düzeni öğrenir, bireysel görünürlügünü arttırır ve olası firsatlar hakkında bilgi edinir. Mentorların, mentilerin bu zorluklarla başa çıkabileceğinden emin olması gerekmektedir. Görünürlüğü arttıracak görevlerdeki başarısızlık mentinin özgüvenine ve mentorun itibarına zarar verir. Dolayısıyla, bu fonksiyon yerine getirilirken, mentinin performansına bağlı olarak mentorun itibar1 yükselebileceği gibi zarar da görebilir (Dougherty, Turban ve Haggard, 2007; Educause, b.t.; Greenhaus ve Singh, 2007; Johnson ve Ridley, 2004).

\section{Psikososyal fonksiyon}

Psikososyal işlev, mentoru, menti için rol model ve destek sunma sistemi olarak kabul etmektedir (APA, 2006). Kariyer fonksiyonları, ilişkinin, mentinin kariyerinde başarılı olmasına yarayacak yönlerine odaklanırken psikososyal fonksiyonlar, mentinin meslekî yetkinlik ve meslekî kimliğini ilerletecek türden kişisel ilişkiler boyutuna odaklanmaktadır. Dolayısıyla, kariyer fonksiyonları bir ölçüde mentorun mentiye kariyer firsatları sunması ya da firsatlar oluşturmasıyla ilgiliyken psikososyal fonksiyonlar mentor ve menti arasındaki ilişkinin niteliğine bağlıdır. 
Psikososyal fonksiyonlar, mentorluk ilişkilerinin kişilerarası boyutlarına işaret eder ve mentinin yetkinlik, öz yeterlik, meslekî ve kişisel gelişimini ilerletmeyi hedefler. Psikososyal fonksiyonlar kişilerarası ilişkinin kalitesine ve ilişkinin ardında yatan duygusal bağlara göre şekil alır. Psikososyal fonksiyonlar, mentiyi daha çok kişisel düzeyde etkilemektedir ve mentinin bireysel gelişimi ve hayatın diğer alanlarına uzanmaktadır (Ragins ve Cotton, 1999).

\section{Arkadaşlık}

$\mathrm{Bu}$ fonksiyon, mentinin kendini mentoruyla eş değer görmesine olanak sağlar ve tarafların daha rahat etkileşime girmesine firsat verir. Sosyal etkileşim, iş ve iş dışı tecrübelerin paylaşılması ile karşılıklı sevgi ve anlayışla sonuçlanır. Kıdemi düşük meslektaş mentoruyla eşit düzeyde olduğunu hisseder (Educause, b.t.; Fagenson-Eland ve Lu, 2004; Greenhaus ve Singh, 2007).

\section{Rol model olma}

Genel olarak mentorlar, menti tarafindan tutumları, değerleri ve davranışlarına öykünülecek rol model olarak işlev görürler. Rol model olarak mentor, mentiye örnek teşkil eder ve mentinin ileride sahip olmak istediği bakış açısını sergiler (Dougherty, Turban ve Haggard, 2007; Haines, 2003).

Her ne kadar Scandura (1992) tarafindan kariyer geliştirme fonksiyonu ve psikososyal fonksiyona ilaveten üçüncü bir fonksiyon olduğu öne sürülse de alanyazında psikososyal fonksiyonun altında sınıflandırılmış olan rol model olma, mentinin kendini mentorla özdeşleştirdiği ve mentora özendiği bir süreçtir. Bilinçli ya da bilinçsiz bir biçimde, menti, mentorun tutumlarını, değerlerini ve davranışlarını taklit etmeye değer bulur. Mentinin meslekî bakımdan kim olduğunu yeniden belirlemesine yardımcı olur. Tanımlama ve aktarım, mentorun, kendi tecrübesinin kıymet gördügünü fark etmesini sağlar (Chao, 2007; Educause, b.t.; Fagenson-Eland ve Lu, 2004)

\section{Danışmanlık}

Danışmanlık yapan bir mentor, mentinin gelişimini engelleyebilecek kişisel kaygılarını gözden geçirmesi için güvenli bir ortam sunar. Mentor, mentinin kendisine dair olumlu algısını ve kariyer hedeflerine ulaşmasını olumsuz etkileyebilecek konuların farkına varmasını sağlar. $\mathrm{Bu}$ süreçte 
mentor, mentiyi kabullenir, destek sunar ve empati gösterir (Dougherty, Turban ve Haggard, 2007; Educause, b.t.; Greenhaus ve Singh, 2007).

\section{Kabul etme ve doğrulama}

Başka bireyi kabul etme ve doğrulama ile destekleme ve cesaretlendirme gerçekleştirilmiş olur. Böylelikle mentinin yeni davranış edinme girişimleri için güvenli bir ortam sağlanır. Temel güven inşa edilir ve yeni davranışların tecrübe edilmesine yönelik risk alma teşvik edilir. Mentor, yaşlanma ve kariyerinin sonuna gelme durumuyla karşı karşıyadır ve mentinin duyduğu minnet mentorun sunduğu desteğin değer gördüğünü fark etmesini sağlar (Dougherty, Turban ve Haggard, 2007; Educause, b.t.; Greenhaus ve Singh, 2007).

\section{Okul yöneticisinin mentorluk rolü}

İçerisinde yer aldığ toplumun değerlerini, yaşam felsefesini paylaşan ve toplumun hedeflerini yerine getirme potansiyeline sahip bireyler yetiştirmek, eğitim örgütleri olan okulların temel görevlerindendir. Okulların bu görevleri yerine getirebilmesi noktasında ise okul yöneticileri önem taş1maktadır. Müdür yardımcılarının yetiştirilmesi sürecinde okul müdürleri önem taşımaktadır. Mentorluk süreci sayesinde okul yöneticileri bilgi bakımından donanım kazanmanın yanında örgütsel amaçlara ilişkin duygusal açıdan da hazırlanmış olacaktır (Ereş, 2009; Sezgin, Koşar ve Er, 2014). Ancak, çalışanların kariyer ve kişisel gelişiminin desteklemesi bakımından önemli ölçüde ilgi gören mentorluk ilişkileri, olumlu getirileri garanti altına almaz. Mentorluk, okul lideri yetiştirme yöntemleri arasında yalnızca bir tanesidir (Allen ve Eby, 2003; Walker ve Stott, 2004).

Okul yöneticilerinin yeteneği besleyerek, kişisel gelişime ilham vererek ve başarıyı teşvik ederek mentorluk ilişkilerinde yer almasının sağlanması, mentorluk yoluyla okul amaçlarına ulaşılmasının ve okulun etkili bir biçimde yönetilmesinin kolaylaşması açısından önem taşımaktadır. Baş döndürücü hızla ortaya çıkan değişikliklerin yaşandığı çağımızda bu değişime ayak uyduracak liderler olan okul yöneticilerinin gerçek potansiyellerine ulaşmasında mentorluk hızlandırıcı bir rol üstlenmektedir (Marquardt ve Loan, 2006; Yirci, 2009). 


\section{İş Doyumu}

İş doyumu, hem işyerlerinde çalışan kişiler hem de konu üzerine çalışma yürüten kişiler için ilgi çekici bir araştırma alanıdır. Örgütsel davranış alanında üzerinde en çok çalışma yürütülmüş değişkendir. Judge ve ark. (2001), örgütsel davranış alanında üzerine iş doyumundan daha çok araştırma yürütülmüş bir konu olmadığını iddia etmektedir. İş doyumu, hem araştırma hem de kuram bakımından, işin niteliklerinin tespit edilmesinden işin yönetimine kadar örgütsel olayların merkezinde yer alan bir değişkendir. Örgütsel davranış ve ilgili alan yayınlarında, iş tatmini üzerine yapılmış binlerce çalışma bulmak mümkündür (Spector, 1997).

Günlük hayatta olduğu kadar bilimsel araştırmalarda yaygın kullanılan, akademik yazında uzun bir geçmişe sahip iş doyumu kavramının tanımına dair bir fikir birliği bulunmamaktadır (Alegre, Mas-Machuca ve Bebegal-Mirabent, 2016; Aziri, 2011). Locke, iş doyumunun duygusal bir tepki olmasından dolayı kavramın anlamının, yalnızca iç gözlem yoluyla keşfedilebileceğini ve algilanabileceğini öne sürmektedir. Yazara göre iş doyumu, bireyin işine ya da iş tecrübelerine atfettiği değere bağlı olarak ortaya çıkan mutluluk veren ya da olumlu duygusal durumdur. İş doyumu, çalışılan işin kişinin bireysel değerleriyle örtüştüğü sürece kendi iş beklentilerini karşılamasından ya da karşılamasını sağlamasından kaynaklanan algılarıdır (Locke, 1976).

Özkalp ve Kırel, kişilerin işlerine karşı geliştirdikleri tutumu iş doyumu olarak adlandırmaktadır. İş doyumu, kişinin kendi algıları çerçevesinde ortaya çıkan bir değerlendirmeye dayanır. İş doyumu, kişinin işe karşı geliştirdiği duygusal ve dolayısıyla doğrudan gözlemlenemeyen ancak kişinin davranışlarına yansıyan tutumlardır. İş doyumu kişinin işine yönelik algılarının sonucu olarak ortaya çıkar ve kişinin önem atfettiği şeylerin karşılanma düzeyine göre farklılık gösterebilir. Çalışan tarafından işe karşı olumlu tutum geliştirildiyse iş doyumunun yüksek olduğu, olumsuz tutum geliştirildiyse iş doyumunun düşük olduğu değerlendirilir (Özkalp ve Kırel, 2013).

\section{İş doyumuna etki eden faktörler}

Çalışanların işlerini sevmesini ya da nefret etmesine yol açan şey nedir? Hough ve Ones, bu soruya, beceri çeşitliliği, görev tanımı, görevin önemi, otonomi, geri bildirim gibi iş özellikleri, rol karmaşası ve rol belirsiz- 
liği gibi rol değişkenleri ve ücretlendirme gibi örgütsel değişkenler incelenerek cevap aranmaya çalışıldığını belirtmektedir (Hough ve Ones, 2005). Bununla birlikte Locke (1976), iş doyumu üzerine yürütülen çalışmaların işin kendisi, ücret, terfi, itibar, işin sağladığ fayda, çalışma koşulları, yönetim, iş arkadaşları gibi boyutlara odaklandığını tespit etmiştir. Robbins'e (2003) göre, iş doyumu sağlayan en önemli faktörler zekâ bakımından zorlayıc1 olan iş, adil ödüllendirme, destekleyici iş koşulları ve destekleyici iş arkadaşlarıdır.

\section{Okul yönetimi ve iş doyumu}

İş doyumu, karmaşık bir yapıdır ve birçok ilişki iş doyumunun şekillenmesinde rol oynar. Örgüler, çalışan iş doyumunu tesis etmek için örgütsel adanmışlığı, iş-aile dengesini sağlayacak, çalışanların bağımsız hareket etmesini destekleyecek, yönetici desteği ve takım çalışması yoluyla işbirliği algısını yönlendirecek uygulamalar ya da girişimler geliştirmelidir. Bir eğitim örgütü olan okullardaki çalışanların performanslarını olumlu yönde geliştirmek, iş doyumundan, çalışma koşullarından ve öğretmenlerin öğretme konusundaki motivasyonundan etkilenmektedir. Okul çalışanlarının iş doyumunu arttırmak, müdürün liderliğiyle alakalıdır; kaynakların yönetiminde müdür rolü, okul çalışanlarının iş doyumuna ulaşmasını sağlamaya katkı sunar (Alegre, Mas-Machuca ve Bebegal-Mirabent, 2016; Amin, 2015).

Alanyazın incelendiğinde mentorluk ve mentorluğun eğitim alanında kullanılması üzerine yabancı (Achinstein ve Fogo, 2015; Birman, Desimone, Porter ve Garet, 2000; Douglas, 1997; Hobson ve Malderez, 2013; Izadinia, 2016; Orland-Barak, 2014; Yuan, 2016) ve yerli (Bakioğlu ve Hacıfazlığlu, 2013; Karadă̆, 2015; Kocabaş ve Yirci, 2011; Özdemir, 2012; Yirci, 2009; Yirci ve Kocabaş, 2010; Yirci, Özdemir, Kartal, Kocabaş ve Aksu, 2015) çeşitli çalışmalar yapıldığı görülmüştür. Bununla birlikte, çalışanların etkililik düzeyi ve uzun vadeli başarısına etki etmesinden dolayı iş doyumu üzerine çok fazla çalışma yapılmıştır (Mukhtar, 2012). Ancak, okul müdürlerinin mentorluk fonksiyonları ve müdür yardımcılarının iş doyumu arasındaki ilişki üzerine yürütülmüş bir çalışma bulunamamıştır.

Yerine getirilecek görevler bakımından kıdemli olan okul müdürünün, müdür yardımcılarına yönelik mentorluk hizmeti sunmasının, okul örgütünün hedeflerine ulaşılmasının kolaylaştırılması ve görevleri yerine getirecek 
olan müdür yardımcılarının iş doyumuna ulaşmasının sağlanması açısından önem taşıdığı değerlendirilmektedir. Bu açıdan, okul müdürlerinin sergiledikleri mentorluk fonksiyonlarının müdür yardımcılarının ulaştığı iş doyumunu yordama düzeyinin belirlenmesinin eğitim yönetimi alanına katkı sunacağı düşünülmektedir. $\mathrm{Bu}$ çalışmayla, okul müdürlerinin sergiledikleri mentorluk fonksiyonlarının müdür yardımcılarının iş doyumunu yordama düzeyinin incelenmesi amaçlanmıştır.

\section{Yöntem}

$\mathrm{Bu}$ çalışmada, okul müdürlerinin sergiledikleri mentorluk fonksiyonlarının müdür yardımcılarının iş doyumlarını yordama düzeyi incelenmiştir. Araştırma ilişkisel tarama modelinde gerçekleştirilmiştir.

\section{Evren ve Örneklem}

Araştırmanın evrenini, 2015-2016 eğitim-öğretim y1lında İstanbul ilindeki anaokul, ilkokul, ortaokul ve lise türü kamu okullarında görev yapan müdür başyardımcısı ve müdür yardımcıları oluşturmaktadır. Araştırmanın örneklemini kolayda örnekleme yöntemiyle belirlenen 2015-2016 eğitim-öğretim yılında Bakırköy, Eyüp, Gaziosmanpaşa ve Kâğıthane ilçelerindeki anaokul, ilkokul, ortaokul ve lise türü kamu okullarında çalışan müdür başyardımcısı ve müdür yardımcıları oluşturmaktadır. İstanbul İl Millî Eğitim Müdürlügü (2015) verilerine göre 2015-2016 eğitim-öğretim yılında İstanbul ilindeki anaokul, ilkokul, ortaokul ve lise türü kamu okullarında 6.302 müdür başyardımcısı ve müdür yardımcısı görev yaparken, Bakırköy ilçesinde 94, Eyüp ilçesinde 164, Gaziosmanpaşa ilçesinde 185 ve Kâğıthane ilçesinde 168 olmak üzere evrende toplam 611 müdür başyardımcısı ve müdür yardımcısı görev yapmaktadır. Gönüllülük esasına dayalı olarak yürütülen bu araştırmada, örneklemde yer alan 611 müdür başyardımcısı ve/veya müdür yardımcısından 402 kişi çalışmaya katılım göstermiştir. Katılım oranı $\% 65.78$ olarak tespit edilmiştir.

Araştırmaya katılan 402 müdür başyardımcısı ve/veya müdür yardımcısının çalıştığı kurum türü, eğitim durumu, meslek kıdemi ve yöneticilik kıdemi değişkenlerine göre dağılımı Tablo 1'de gösterilmiştir.

Tablo 1 incelendiğinde araştırmaya katılan müdür yardımcılarının \%1.49'u anaokulunda ( $\mathrm{N}=6), \% 31.84$ 'ü ilkokulda $(\mathrm{N}=128), \% 24.38$ 'i ortaokulda ( $\mathrm{N}=98)$ ve \%42.29'u da lisede $(\mathrm{N}=170)$ çalıştığı görülmektedir. Kat1- 
lımc1ların \%80.30'u lisans düzeyinde ( $N=323)$, \%19.70'i lisansüstü düzeyinde $(\mathrm{N}=79)$ eğitime sahiptir. Katılımcıların \%11.20'sinin meslek kıdemi 0-5 yıl aralığında $(\mathrm{N}=45), \% 23.39$ 'unun meslek kıdemi 6-10 yıl aralığında $(\mathrm{N}=94), \% 28.10$ 'unun meslek kidemi 11-15 y1l aralığında $(\mathrm{N}=113)$ ve \%37.31'inin meslek k1demi 16 yıl ve üzerindedir $(\mathrm{N}=150)$. Katılımcıların \%62.69'unun yöneticilik kıdemi 0-5 yıl aralığında ( $\mathrm{N}=252)$, \%19.65'inin yöneticilik kıdemi 6-10 yıl aralığında $(\mathrm{N}=79), \% 9.95$ 'inin yöneticilik kıdemi 11-15 yıl aralığında $(\mathrm{N}=40)$ ve \%7.71'inin yöneticilik k1demi 16 yıl ve üzerindedir $(\mathrm{N}=31)$.

Tablo 1. Katılımcı Müdür Başyardımcısı ve/veya Müdür Yardımcılarının Çalıştığı Kurum Türü, Eğitim Durumu, Meslek Kıdemi ve Yöneticilik K1demi Değişkenlerine Göre Dağılımı

\begin{tabular}{cccc}
\hline & & $\mathbf{N}$ & $\mathbf{\%}$ \\
\hline \multirow{3}{*}{ Kurum Türü } & Anaokulu & 6 & 1.49 \\
& İlkokul & 128 & 31.84 \\
& Ortaokul & 98 & 24.38 \\
& Lise & 170 & 42.29 \\
\hline \multirow{2}{*}{ Ĕgitim Durumu } & Lisans & 323 & 80.30 \\
& Lisansüstü & 79 & 19.70 \\
\hline \multirow{3}{*}{ Meslek Kıdemi } & $0-5$ yıl & 45 & 11.20 \\
& $6-10$ yıl & 94 & 23.39 \\
& $11-15$ yıl & 113 & 28.10 \\
& 16 yıl ve üzeri & 150 & 37.31 \\
\hline \multirow{3}{*}{ Yöneticilik Kıdemi } & $0-5$ yıl & 252 & 62.69 \\
& $6-10$ yıl & 79 & 19.65 \\
& $11-15$ yıl & 40 & 9.95 \\
& 16 yıl ve üzeri & 31 & 7.71 \\
\hline
\end{tabular}

Araştırmaya katılan 402 müdür yardımcısının çalıştığı kurum türü, branş, cinsiyet, yaş aralığı, eğitim durumu, meslek kıdemi ve yöneticilik kıdemi değişkenlerine göre dağılımı Tablo 2'de gösterilmiştir.

Tablo 2 incelendiğinde, araştırmaya katılan müdür yardımcılarının birlikte çalıştığı müdürlerin \%68.70'i lisans düzeyinde (N=267), \%31.30'u lisansüstü düzeyinde (N=123) eğitime sahip olduğu görülmektedir. Araştırmaya katılan müdür yardımcılarının birlikte çalıştıkları okul müdürlerinin \%4.97'sinin meslek kıdemi 0-5 y1l aralığında (N=20), \%10.70'inin meslek 
kıdemi 6-10 yıl aralığında (N=43), \%24.38'inin meslek kıdemi 11-15 yıl aralığında $(\mathrm{N}=98)$ ve \%59.95'inin meslek k1demi 16 yıl ve üzerindedir $(\mathrm{N}=241)$. Araştırmaya katılan müdür yardımcıları ve müdürlerin \%83.33'ünün birlikte çalışma süresi $0-5$ yıl aralığında $(\mathrm{N}=335)$, \%11.94'ünün birlikte çalışma süresi 6-10 yıl aralığında (N=48), \%2.73'ünün birlikte çalışma süresi 11-15 yıl aralığında $(\mathrm{N}=11)$ ve \%1.99'unun birlikte çalışma süresi 16 yıl ve üzerindedir $(\mathrm{N}=8)$.

Tablo 2. Katılımcı Müdür Başyardımcısı ve/veya Müdür Yardımcılarının Müdürlerinin Eğitim Durumu, Meslek Kıdemi ve Müdür Yardımcısıyla Birlikte Çalışma Süresi Değişkenlerine Göre Dağılımı

\begin{tabular}{cccc}
\hline & & $\mathbf{N}$ & $\boldsymbol{\%}$ \\
\hline \multirow{2}{*}{ Eğitim Durumu } & Lisans & 276 & 68.70 \\
& Lisansüstü & 126 & 31.30 \\
\hline \multirow{2}{*}{ Meslek Kıdemi } & $0-5$ yıl & 20 & 4.97 \\
& $6-10$ yıl & 43 & 10.70 \\
& $11-15$ yıl & 98 & 24.38 \\
Müdür Yardımcısılla Birlikte & 16 yıl ve üzeri & 241 & 59.95 \\
Çalışma Süresi & $0-5$ yıll & 335 & 83.33 \\
& $6-10$ yıl & 48 & 11.94 \\
& $11-15$ yıl & 11 & 2.74 \\
& 16 yıl ve üzeri & 8 & 1.99 \\
\hline
\end{tabular}

\section{Veri Toplama Araçları}

Dougherty ve Dreher (2007), mentorluk fonksiyonlarına yönelik yürütülen çalışmaları incelemiştir. Yazarlar, mentorluk fonksiyonlarını ölçmeye yönelik en sık kullanılan ölçeğin, Noe (1988) tarafından geliştirilmiş, kariyer ve psikososyal fonksiyonları ölçmeyi hedefleyen "Mentorluk Fonksiyonları Ölçeği” olduğunu tespit etmiştir. İbrahimoğlu, Uğurlu ve Kızıloğlu (2011) tarafindan Türkçeye uyarlanan, Noe (1988) tarafından geliştirilen, tümü olumlu 29 maddeden oluşan, yöneticilik becerilerini geliştirmek isteyenlere yönelik olarak beşli likert tipinde hazırlanmış "Mentorluk Fonksiyonları Ölçeği” veri toplama aracında kullanılmıştır.

Noe (1988), ölçek geliştirme aşamasında ABD'nin 9 farklı yerleşim yerinde yaşayan 139 eğitici ve 43 mentorun katılımıyla bir çalışma gerçekleştirmiştir. Noe, kariyere yönelik mentorluk fonksiyonlanı ve psikososyal mentorluk fonksiyonları olmak üzere iki faktörlü bir yapı elde etmiştir. Ö1çekte, 14 madde kariyer geliştirme fonksiyonunu, 15 madde psikososyal 
fonksiyonu ölçmektedir. Noe, kariyer fonksiyonlarını ölçen maddelerin iç tutarlılık güvenirlik katsayısını .89 , psikososyal fonksiyonları ölçen maddelerinin iç tutarlılık güvenirlik katsayısını .92 olarak tespit etmiştir.

Ölçme sonucunda elde edilen verilerin uygunluğunu, anlamlılığını ve kullanışlılığına ilişkin çıkarımlarda bulunmanın yolu yapı geçerliliğinin test edilmesinden geçer (Slocum-Gori ve Zumbo, 2010). Ölçekte yer alan maddelerin, ölçülmesi amaçlanan özellikleri ne derecede ölçtüğünün tespit edilmesi, ölçeğin yap1 geçerliliği ile ilgilidir. Ölçeğin yapı geçerliliğinin test edilmesinin yollarından biri de, birbirleriyle ilişki içerisinde olan çok sayıdaki değişkeni bir araya getirerek az sayıda anlamlı yeni değişken bulmayı amaçlayan istatistiksel bir teknik olan açımlayıcı faktör analizidir (Büyüköztürk, 2014; Tabachnick ve Fidell, 2013). Field'e (2009) göre, faktör analizinden elde edilen sonuçların güvenilir kabul edilebilmesi için katılımcı sayısının 300'ün üzerinde olması gerekmektedir. Çalışmada kullanılan, 402 katılımcının cevap verdiği "Mentorluk Fonksiyonları Ölçeği”nin yapı geçerliğini ortaya koymak amacıyla ölçekte bulunan 29 madde üzerinde açımlayıc1 faktör analizi yapılmıştır.

Faktör analizi gerçekleştirilmeden önce, verilerin bu teste uygunluğunu sınamak için Kaiser-Meyer-Olkin (KMO) katsayısı ve Barlett küresellik testi kullanılmaktadır. KMO testinden elde edilen değerler 0 ve 1 arasında değişkenlik gösterir. KMO katsayısının 1'e yakın olduğu ölçüde faktör analizinden elde edilecek verilerin güvenilir olacağı değerlendirilir. Faktörleşmenin geçekleşmesi için bu değerin 0.60'ın üzerinde olması beklenir. Barlett küresellik testinin sonuçlarının anlamlı çıkması, veri matrisinin faktör analizine uygunluğunun göstergesi olarak kabul edilmekle birlikte bu durum, puanların dağılımının normalliğinin de kanıtı olarak değerlendirilir (Büyüköztürk, 2014; Field, 2009). Veri yapısının faktör analizine uygunluğunun test edilmesi amacıyla 29 maddelik Mentorluk Fonksiyonları Ölçeği'nden elde edilen 402 katılımciya ait veri üzerinde KMO ve Barlett küresellik testi gerçekleştirilmiştir. KMO katsayısı 0.97 ve Barlett küresellik testi sonucu $15587.96(p=.000)$ olarak tespit edilmiştir. Gözlemlenen KMO katsayısı Büyüköztürk (2014) tarafindan önerilen 0.60 değerinin üzerindedir ve Barlett küresellik testi sonucu anlamlılık göstermektedir. Bu değerler, Mentorluk Fonksiyonları Ölçeği'nden elde edilen verilerin faktör analizine uygun olduğunu ve verilerin normal dağıldığını göstermektedir. 
Açımlayıcı faktör analizinde faktör sayısını belirlemede Kaiser yöntemi (özdeğer $>1$ ), scree plot testi, açıklanan varyans toplamı ve paralel analiz yöntemleri kullanılmaktadır (Williams, Onsman ve Brown, 2010). Bu yöntemler arasında paralel analiz, açımlayıcı faktör analizi sonucunda elde edilecek faktör sayısının tespitinde en güvenilir sonuçları sağlayan ve ölçeğin boyutlarının tespit edilmesinde kullanılması tavsiye edilen bir yöntemdir (Garrido, Abad ve Ponsoda, 2013; Schmitt, 2011). Paralel analiz yönteminde ölçekten elde edilmiş veri ile aynı sayıda katılımcı ve ölçek maddesi içeren tesadüfî bir korelasyon matrisi üretilir. Bu matrise uygulanan temel bileşen analizi sonunda elde edilen özdeğerler ile gerçek veriden elde edilen özdeğerler kıyaslanır. Faktör sayısı, gerçek verilere ait özdeğerin tesadüfî verilere ait özdeğerden büyük olduğu nokta olarak belirlenir (O'Connor, 2000; Yavuz ve Doğan, 2015). Brown'a (2006) göre gerçek veriden elde edilen faktörün açıkladığı varyans oranının rastgele veriden elde edilen faktörün açıkladığı varyans oranından düşük olması durumunda ilgili madde faktör olarak kabul edilmemelidir.

Mplus (v7) yazılımıyla gerçekleştirilen paralel analize göre gerçek veriden elde edilen özdeğerin tesadüfî veriden elde edilen özdeğerden yüksek olduğu bir adet faktör bulunmaktadır. Elde edilen bu faktörün gerçek verideki özdeğeri 21.08 , tesadüfî verideki özdeğeri 1.53 'tür. İkinci sırada bulunan bileşene ilişkin olarak gerçek veriden elde edilen bileşenin açıkladığı varyans oranı 3.87 iken rastgele veriden elde edilen bileşenin açıkladığ varyans oranı 5.02'dir. Bu durum, Brown (2006) tarafından belirtilen, gerçek veriden elde edilen faktörün açıkladığı varyans oranının rastgele olandan elde edilene göre daha düşük olması durumunda ilgili maddenin faktör olarak kabul edilemeyeceği biçimindeki kritere uygundur. Mentorluk fonksiyonları ölçeğine uygulanan açımlayıcı faktör analizi sonucunda elde edilen tek faktör, toplam varyansın \%72.70'ini açıklamaktadır.

Değişkenler arasındaki ilişkinin bir hipotez ya da kuramın sınanmasında, örtük yapılar arasındaki ilişkilerin incelenmesinde başvurulan doğrulayıcı faktör analizi, geçerlilik analizlerinde kullanılmaktadır (Büyüköztürk, 2014; Jackson, Gillaspy ve Purc-Stephenson, 2009; Yavuz ve Doğan, 2015). Veriler ile modelin uyumunun doğrulanması için doğrulayıcı faktör analizinden elde edilen; 
- Chi kare $\left(\chi^{2}\right)$ değerinin serbestlik derecesine (sd) bölümünün $\left(\chi^{2} / s d\right)$ 2 ile 3 aralığında olması,

- TLI (Tucker-Lewis Index) değerinin (0 ile 1 aralığında değişim göstermektedir) 0.95 ve üzerinde olmas1,

- CFI (Comparative Fit Index) değerinin (0 ile 1 arasında değişim göstermektedir) 0.95 ve üzerinde olmas1,

- SRMR (Standardized Root Mean Square Residual) değerinin 0.1'in altında olmasi,

- RMSEA (Root Mean Square Error of Approximation) değerinin 0.08'in altında olması gerekmektedir (Brown, 2015; Hoe, 2008; Hu ve Bentler, 1999; Kline, 2011; Schermelleh-Engel, Moosbrugger ve Müller, 2003; Schreiber, Nora, Stage, Barlow ve King, 2006; Thompson, 2004).

Mentorluk Fonksiyonları Ölçeği’ne uygulanan açımlayıcı faktör analizi ile ortaya çıkan tek faktörlü yapının geçerliliğini doğrulamak için Mplus (v7) yazılımı kullanılarak doğrulayıcı faktör analizi gerçekleştirilmiştir. Doğrulayıcı faktör analizi model doğrulaması için referans değerler ve mentorluk fonksiyonları ölçeği için öngörülen tek faktörlü yapıya sahip modele ilişskin doğrulayıcı faktör analizinden elde edilen değerler şu şekildedir: $\chi^{2} / \mathrm{sd}=3.03$, TLI $=0.94, \mathrm{CFI}=0.95, \mathrm{SRMR}=0.02$, RMSEA $=0.07$. Sonuçlar bütüncül olarak ele alındığında, Mentorluk Fonksiyonları Ölçeği’nin tek faktörden oluşan yapısının referans değerlere uygun olduğu, tek faktörlü yapının doğrulandığı görülmektedir. Elde edilen tek faktörlü yapı, Şerefhanoğlu (2014) tarafindan tespit edilen tek faktörlü yapıyla uyumludur.

Testin ölçmeyi hedeflediği özellikleri doğru ölçme derecesi, testin güvenirliği olarak ifade edilmektedir. Güvenirlik, bir korelasyon katsayısı ile ifade edilir ve 0 ile 1 arasında bir değer alır. Testin güvenirlik katsayısını hesaplamada kullanılan Cronbach Alfa katsayısı, derecelendirme ölçeklerinin yer aldığı çalışmalarda sıklıkla kullanılmaktadır (Büyüköztürk, Çakmak, Akgün, Karadeniz ve Demirel, 2014; Karasar, 2014). Can'a (2014) göre, güvenirlik katsayısı 1'e yakın olduğu oranda ölçek güvenilir olarak kabul edilir.

Mentorluk Fonksiyonları Ölçeği'nin Cronbach Alfa güvenirlik kat sayısına ilişkin olarak, araştırmalarında Şerefhanoğlu (2014) $\alpha=.97$; Kennedy (2013) $\alpha=.92$ olarak tespit etmiştir. Bu çalışmada bu değer .98 olarak tespit 
edilmiştir. Bu bakımdan Mentorluk Fonksiyonları Ölçeği’nin yüksek derecede güvenilir olduğu söylenebilir.

İş doyumuna yönelik yürütülen araştırmalarda en yaygın olarak kullanılan ölçek "Minnesota Doyum Ölçeği”dir (Aziri, 2011; Judge ve ark., 2001; Spector, 1997). Uzun formu 100 maddeden oluşan, Weiss ve ark. (1967) tarafindan geliştirilen, Baycan (1982) tarafından Türkçeye uyarlanan, beşli likert tipinde hazırlanmış 20 maddeden oluşan "Minnesota Doyum Ölçeği Kısa Formu"nun 1977 yılında düzenlenen versiyonu veri toplama aracında kullanılmıştır.

Weiss ve ark. (1967), ölçek geliştirme aşamasında muhasebeci, mühendis, yönetici, hemşire, öğretmen, iş makinesi operatörü, sekreter, kamyon şoförü gibi çok farklı işs sahalarından 1460 iş görenin katılımıyla bir çalışma yürütmüştür. Weiss ve ark., iç doyum ve dış doyum olmak üzere iki faktörlü bir yap1 elde etmiştir. Weiss ve ark., meslek gruplarına göre farklılık göstermekle birlikte iç doyumu ölçen maddelerin Hoyt iç tutarlılık katsayısının .84 ile .91 arasında değiştiğini, dış doyumu ölçen maddelerin Hoyt iç tutarl1lık katsayısının .77 ile .82 arasında değiştiğini tespit etmiştir.

Çalışmada kullanılan, 402 katılımcının cevap verdiği Minnesota Doyum Ölçeği'nin yapı geçerliğini ortaya koymak amacıyla ölçekte bulunan 20 madde üzerinde açımlayıcı faktör analizi yapılmıştır. Veri yapısının faktör analizine uygunluğunun test edilmesi amaciyla KMO ve Barlett küresellik testi gerçekleştirilmiştir. KMO katsayısı 0.94 ve Barlett küresellik testi sonucu $5221.33(p=.000)$ olarak tespit edilmiştir. Gözlemlenen KMO katsayıs1 Büyüköztürk (2014) tarafindan önerilen 0.60 değerinin üzerindedir ve Barlett küresellik testi sonucu anlamlılık göstermektedir. Bu değerler, İş Doyumu Ölçeği'nden elde edilen verilerin faktör analizine uygun olduğunu ve verilerin normal dağıldığını göstermektedir.

Mplus (v7) yazılımıyla gerçekleştirilen paralel analize göre gerçek veriden elde edilen özdeğerin tesadüfî veriden elde edilen özdeğerden yüksek olduğu bir adet faktör bulunmaktadır. Bu faktörün gerçek verideki özdeğeri 10.03 , tesadüfî verideki özdeğeri 1.42 'dir. İkinci sırada bulunan bileşene ilişkin olarak gerçek veriden elde edilen bileşenin açıkladığı varyans oranı 6.34 iken rastgele veriden elde edilen bileşenin açıkladığ 1 varyans oranı 6.70'tir. Bu durum, Brown (2006) tarafından belirtilen, gerçek veriden elde 
edilen faktörün açıkladığı varyans oranının rastgele olandan elde edilene göre daha düşük olması durumunda ilgili maddenin faktör olarak kabul edilemeyeceği biçimindeki kritere uygundur. İş Doyumu Ölçeği'ne uygulanan açımlayıcı faktör analizi sonucunda elde edilen tek faktör, toplam varyansın \%50.16'sını açıklamaktadır.

İş Doyumu Ölçeği’ne uygulanan açımlayıcı faktör analizi ile ortaya çıkan tek faktörlü yapının geçerliliğini doğrulamak için doğrulayıcı faktör analizi gerçekleştirilmiştir. İş Doyumu Ölçeği'ne uygulanan, Mplus (v7) yazılımıyla gerçekleştirilen doğrulayıcı faktör analizinden elde edilen değerler şu şekildedir: $\chi^{2} / \mathrm{df}=2.33, \quad \mathrm{TLI}=0.95, \quad \mathrm{CFI}=0.96, \quad$ SRMR $=0.03$, RMSEA $=0.05$. Sonuçlar bütüncül olarak ele alındığında, İş Doyumu Ölçeği'nin tek faktörden oluşan yapısının referans değerlere uygun olduğu, tek faktörlü yapının doğrulandığı görülmektedir. Elde edilen tek faktörlü yap1, Kul (2010) tarafından tespit edilen tek faktörlü yapıyla uyumludur.

Minnesota Doyum Ölçeği kısa formunun Cronbach Alfa güvenirlik kat sayısına ilişkin olarak, araştırmalarında Gündüz, Çapri ve Gökçakan (2013) $\alpha=.91$; Hall (2008) $\alpha=.85$ olarak tespit etmiştir. Bu çalışmada bu değer 94 olarak tespit edilmiştir. Bu bakımdan Minnesota Doyum Ölçeği kısa formunun yüksek derecede güvenilir olduğu söylenebilir.

\section{Verilerin Çözümlenmesi}

Veri toplama aracının uygulanması neticesinde elde edilen veriler IBM SPSS Statistics (v22) paket programı yardımıyla analiz edilmiştir. Elde edilen puanlara ilişkin frekans ve yüzde dağılımları hesaplanmış, aritmetik ortalama ve standart sapma gibi tanımlayıc istatistik bilgilerinden de yararlanılmıştır.

İki değişken arasında var olan ilişkinin miktarını tespit etmek için Pearson Korelasyon katsayısı (r) kullanılır. +1 ile -1 aralığında değerler alan korelasyon katsayısı için:

$1.00<|\mathrm{r}|<0.70$ yüksek düzeyde korelasyon,

$0.70<|\mathrm{r}|<0.30$ orta düzeyde korelasyon,

$0.30<|\mathrm{r}|<0.00$ düşük düzeyde korelasyon olarak yorumlanır. 
Değişkenler arasındaki ilişki pozitif ya da negatiftir. Pozitif ilişki, değişkenlerden birisi artarken diğerinin de artma eğiliminde, değişkenlerden biri düşerken diğerinin de düşme eğiliminde olduğunu ifade eder. Negatif ilişki, değişkenlerden biri artarken diğerinin düşme eğiliminde olduğunu ifade eder (Büyüköztürk, 2014; Field, 2009).

Aralarında korelasyon bulunan iki değişken arasındaki ilişki için, bağımsız değişkende gözlenen değişimin bağımlı değişkende ortaya çıkan değişimi açıklama oranını tespit etmek için basit doğrusal regresyon testi kullanılır. Test sayesinde değişkenler arasındaki ilişki, matematiksel eşitlik olarak ifade edilebilir (Büyüköztürk, 2014).

\section{Bulgular}

Müdür yardımcılarının iş doyum düzeyleri ile okul müdürlerinin sergilediği mentorluk fonksiyonları arasında ilişki olup olmadığını tespit etmek için basit doğrusal korelasyon analizi gerçekleştirilmiştir. Test sonuçları Tablo 3'te yer almaktadır.

Tablo 3. Mentorluk Fonksiyonları ile İş Doyumu Arasındaki İlişkiye Dair Pearson Korelasyon Matrisi

\begin{tabular}{lcc}
\hline & Mentorluk Fonksiyonları & İş Doyumu \\
\hline Mentorluk Fonksiyonları & .58 & .58 \\
İş Doyumu & .58 & \\
\hline
\end{tabular}

Tablo 3'te okul müdürlerinin sergiledikleri mentorluk fonksiyonları ile müdür yardımcılarının iş doyumu düzeyleri arasında bir ilişkinin olup olmadığını ortaya koymak için gerçekleştirilen basit doğrusal korelasyon analizi sonuçları görülmektedir. Elde edilen sonuçlara göre okul müdürlerinin sergiledikleri mentorluk fonksiyonları ile müdür yardımcılarının iş doyumu arasında orta düzeyde, pozitif yönde ve istatistiksel bakımdan anlamlı bir ilişki vardır $(\mathrm{r}=.58, p=.000<.05)$.

Okul müdürlerinin sergilediği mentorluk fonksiyonlarının müdür yardımcılarının iş doyum düzeylerinin yordayıcısı olup olmadığını tespit etmek için basit doğrusal regresyon analizi gerçekleştirilmiştir. Mentorluk Fonksiyonları Ölçeği'nden elde edilen puan bağımsız (açıklayıcı) değişken, İş Doyumu Ölçeği'nden elde edilen puan bağımlı (açıklanan) değişken olarak belirlenmiştir. Test sonucunda elde edilen veriler Tablo 4'te yer almaktadır. 
Tablo 4. Okul Müdürlerinin Sergiledikleri Mentorluk Fonksiyonlarının Müdür Yardımcılarının İş Doyumunu Yordamasına İlişkin Basit Doğrusal Regresyon Analizi

\begin{tabular}{lccccccc}
\hline Değişken & B & Std. Hata & $\boldsymbol{\beta}$ & $\mathbf{t}$ & $\boldsymbol{p}$ & Sapmasız r & Kısmi r \\
\hline Sabit & 2.434 & .10 & & 22.94 & .000 & & \\
$\begin{array}{l}\text { Mentorluk } \\
\text { Fonksiyonlar }\end{array}$ & 0.383 & .02 & .583 & 14.35 & .000 & .583 & .583 \\
\hline $\begin{array}{l}\mathrm{R}=0.583 \\
\mathrm{~F}_{(1,400)}=205.93\end{array}$ & $\begin{array}{l}\mathrm{R}^{2}=0.340 \\
p=.000\end{array}$ & & & & \\
\hline
\end{tabular}

Tablo 4 incelendiğinde, okul müdürlerinin sergiledikleri mentorluk fonksiyonları ile müdür yardımcıların iş doyumu arasında anlamlı bir ilişki gözlemlenmekte $\left(\mathrm{R}=0.583, \mathrm{R}^{2}=0.340\right)$, okul müdürleri tarafindan sergilenen mentorluk fonksiyonlarının müdür yardımcılarının iş doyumunun anlamlı bir yordayıc1sı olduğu görülmektedir $\left[\mathrm{F}_{(1,400)}=205.93, p=.000<.05\right]$. Okul müdürlerinin sergilediği mentorluk fonksiyonları, müdür yardımcılarının iş doyumunun \%34'ünü açıklamaktadır. Regresyon denklemine esas yordayıcı değişken katsayısının $(\mathrm{B}=0.383)$ anlamlılık testi de, okul müdürlerinin sergilediği mentorluk fonksiyonlarının anlamlı bir yordayıcı olduğunu göstermektedir $(p=.000<.05)$.

Regresyon analizi sonucuna göre, müdür yardımcılarının iş doyumunu yordayan regresyon denklemi şu şekildedir:

İş Doyumu $=(0.383 *$ Mentorluk $)+2.434$

$\mathrm{Bu}$ sonuç, okul müdürlerin müdür yardımcılarının iş doyumuna ulaşma düzeyini arttırmak için mentorluk fonksiyonlarını en üst düzeyde sergilemeleri gerektiğini ortaya koymaktadır.

\section{Tartışma ve Sonuç}

$\mathrm{Bu}$ çalışma ile okul müdürlerinin sergiledikleri mentorluk fonksiyonlarının müdür yardımcılarının iş doyumu düzeyi için anlamlı bir yordayıcı olup olmadığı sorusuna cevap aranmıştır.

Gerçekleştirilen regresyon analizi sonucuna göre okul müdürlerinin sergiledikleri mentorluk fonksiyonları ile müdür yardımcılarının iş doyumu arasında orta düzeyde, pozitif yönde ve istatistiksel açıdan anlamlı bir ilişki 
olduğu sonucuna ulaşılmıştır. Okul müdürlerinin sergiledikleri mentorluk fonksiyonlarının müdür yardımcılarının iş doyumu düzeyi için anlamlı bir yordayıcı olduğu tespit edilmiştir. Ulaşılan bu sonuç Anderson (2010), Allen ve ark. (2004), Appelbaum, Ritchie ve Shapiro (1994), Karakuş ve Tok (2015), Kim (2011), Kennedy (2013) ve Morrison (2009) tarafından ulaşılan sonuçları destekler niteliktedir.

Karakuş ve Tok (2015), sınıf öğretmenlerinin ulaştıkları iş doyumu düzeyi ve okul yöneticilerinin sergiledikleri mentorluk fonksiyonları arasındaki ilişkiyi incelemiştir. Karakuş ve Tok'a göre, sınıf öğretmenlerinin iş doyumuna ulaşma düzeyleri ile okul yöneticilerinin sergilediği mentorluk fonksiyonları arasında pozitif yönde, doğru orantılı, düşük düzeyde bir ilişki vardır. Araştırmaya göre okul yöneticileri tarafından sergilenen mentorluk fonksiyonları arttıkça sınıf öğretmenlerinin iş doyumuna ulaşma seviyesi de artmaktadır. Benzer bir şekilde Kennedy (2013) de iş doyumuna ulaşma düzeyi ile mentorluk fonksiyonlarının sergilenmesi arasında pozitif yönlü düşük düzeyli bir ilişki olduğunu tespit etmiştir.

Allen ve ark. (2004), mentorluk sürecine dahil olan bireylerin iş doyumuna ulaşma düzeyinin daha yüksek olduğunu tespit etmiştir. Allen ve ark., mentorluk sürecine dahil olan iş görenlerin, iş doyumsuzluğunun sonuçlarından olan işten ayrılma eğiliminden uzaklaştığını ifade etmektedir. Appelbaum, Ritchie ve Shapiro, (1994), mentorluk ve iş doyumu arasında iki boyutlu bir ilişki olduğunu saptamıştır. Çalışmaya göre, işe kendini adama ile mentorluk arasında olumlu; devamsızlık ya da işten ayrılma şeklinde ortaya çıkan iş doyumsuzluğu arasında negatif bir ilişki vardır. Kim (2011), mentorluk sürecinin örgüt üyelerinin kariyerlerinde ilerlemeyi ve meslektaşlar arasında iyi ilişkilerin gelişimini desteklediğini ve buna bağlı olarak çal1şanın iş doyumunu arttırdığını tespit etmiştir.

Mentorluk sürecinin mentilere sağladığı faydalar üzerine çeşitli çalışmalar gerçekleştirilmiştir (Abdullah, Rossy, Ploeg, Davies, Higuchi, Sikora ve Stacey, 2014; Alayoğlu, 2012; Allen ve ark., 2004; Arora ve Rangnekar, 2016; Eby, Allen, Evans, Ng ve DuBois, 2008; Haynes ve Ghosh, 2008; Izadina, 2016; İbrahimoğlu, 2013; İşcan ve Çakır, 2016; Kim, 2014; Lo, Ramayah ve Kui, 2013; Noe, Greenberger ve Wang, 2002; Özcan ve Çağlar, 2013; Özdemir ve Boydak-Özkan, 2013; Özkalp ve ark., 2006; Ragins ve 
Cotton, 1999; Ragins ve Kram, 2007; Scandura ve Pellegrini, 2004). Yürütülen bu araştırmalara göre, mentorluk sürecine dahil olan bireylerin bu sürece dahil olmayanlara kıyasla daha fazla iş doyumuna ulaştıkları, daha yüksek ücretlerle çalıştıkları, daha fazla terfi olanağına sahip oldukları, örgütsel iletişimde daha etkin oldukları, çalışma atmosferine daha kolay uyum sağladıkları, daha iyi performans sergiledikleri, daha üretken oldukları, örgütsel bağlılıklarının arttığı, bilgi paylaşımı konusunda daha başarılı oldukları ve liderlik becerileri bakımından ilerleme kaydettikleri belirlenmiştir. $\mathrm{Bu}$ çalışmaların tümünün ortak noktası, mentorluk sürecinin mentilerin ulaştıkları iş doyumu düzeyini arttırdığı noktasında birleşmektedir. Bu bakımdan, bu çalışmayla elde edilen, okul müdürlerinin sergiledikleri mentorluk fonksiyonlarının okul müdür yardımcılarının ulaştıkları iş doyumu düzeyini arttırdığına ilişkin sonuç, anılan çalışmaların sonuçlarıyla benzerlik göstermektedir.

Elde edilen bulgular 1şığında okul müdürlerinin, müdür yardımcılarıyla ilişkilerinde mentorluk fonksiyonlarını ön plana çıkartması gerektiği sonucuna varılmıştır. Bununla birlikte, ülkemizde okul müdürlerine ya da müdür yardımcılarına yönelik formal bir mentorluk programı uygulanmamaktadır. Müdür yardımcılarının iş doyumlarının arttırılması ve örgütsel hedeflere ulaşılmasına bu yolla katkı sağlanması açısından olumlu sonuçlara ulaşabilmek için formal mentorluk programları hazırlanması önerilebilir.

\section{Kaynakça}

Abdullah, G., Rossy, D., Ploeg, J., Davies, B., Higuchi, K., Sikora, L. ve Stacey, D. (2014). Measuring the effectiveness of mentoring as a knowledge translation intervention for implementing empirical evidence: A systematic review. Worldviews On Vidence-Based Nursing, 11(5), 284-300.

Achinstein, B. ve Fogo, B. (2015). Mentoring novices' teaching of historical reasoning: Opportunities for pedagogical content knowledge development through mentor facilitated practice. Teaching and Teacher Education, 45, 45-58.

Akyüz, Y. (2015). Türk eğitim tarihi: M.Ö. 1000 - M.S. 2015. Ankara: Pegem Akademi Yayınları. 
Alayoğlu, N. (2012). Üstadlık: Kadim bir eğitim ve kariyer geliştirme yöntemi. Amme Ídaresi Dergisi, 45(2), 103-131.

Alegre, I., Mas-Machuca, M. ve Bebegal-Mirabent, J. (2016). Antecedents of employee job satisfaction: do they matter? Journal of Business Research, 69, 1390-1395.

Allen, T. D. ve Eby, L. T. (2003). Relationship effectiveness for mentors: Factors associated with learning and quality. Journal of Management, 29(4), 469-486.

Allen, T. D., Eby, L. T., Poteet, M. L., Lentz, E. ve Lima, L. (2004). Career benefits associated with mentoring for protégés: A meta-analysis. Journal of Applied Psychology, 89(1), 127-136.

American Psychological Association (APA). (2006). Introduction to mentoring: A guide for mentors and mentees.

Amin, M. (2015). Relationship between job satisfaction, working conditions, motivation of teachers to teach and job performance of teachers in MTs, Serang, Banten. Journal of Management and Sustainability, 5(3), 141-154.

Anderson, G. B. (2010). The effect of participation in teacher induction and mentor programs and the assignment of mentor teacher on the satisfaction and retention of new teachers. Yayımlanmamıs doktora tezi, Kansas Üniversitesi.

Appelbaum, S. H., Ritchie, S. ve Shapiro, B. T. (1994). Mentoring revisited: An organizational behavior construct. The International Journal of Career Management, 6(3), 3-10.

Arora, R. ve Rangnekar, S. (2016). Moderating mentoring relationships and career resilience: Role of conscientiousness personality disposition. Journal of Workplace Behavioral Health, 31(1), 19-36.

Aziri, B. (2011). Job satisfaction: A literature review. Management Research and Practice, 3(4), 77-86. 
Bakioğlu, A. ve Hacıfazlığlu, Ö. (2013). Mentorluk süreci ve yeni eğilimler. A. Bakioğlu, (Ed.), Eğitimde mentorluk içinde (41-72). Ankara: Nobel Akademi Yayınları.

Balyer, A. (2012). Çağdaş okul müdürlerinin değişen rolleri. Ahi Evran Üniversitesi Eğitim Fakültesi Dergisi, 13(2), 75-93.

Baycan, F. A. (1982). An analysis of the several aspects of job satisfaction between different occupational groups. Yayımlanmamış yüksek lisans tezi, Boğaziçi Üniversitesi.

Birman, B. F., Desimone, L. Porter, A. C. ve Garet, M. S. (2000). Designing professional development that works. Educational Leadership, 57(8), 28-33.

Borredon, L. ve Ingham, M. (2004). Developmental relationships: A mentoring approach to organizational learning and knowledge creation. D. Clutterbuck, ve G. Lane, (Ed.), The situational mentor: An international review of competences and capabilities in mentoring içinde (118-126). Burlington: Gover Publishing.

Brockbank, A. ve McGill, I. (2006). Facilitating reflective learning through mentoring \& coaching. Londra: Kogan Page.

Brown, T. A. (2006). Confirmatory factor analysis for applied research. New York: The Guilford Press.

Brown, T. A. (2015). Confirmatory factor analysis for applied research second edition. New York: The Guilford Press.

Burke, R. J. ve Richardsen, A. M. (2001). Psychological burnout in organizations: Research and intervention. R. T. Golembiewski, (Ed.), Handbook of organizational behavior içinde (327-363). New York: Marcel Dekker, Inc.

Büyüköztürk, Ş. (2014). Sosyal bilimler için veri analizi el kitabı: İstatistik, araştırma deseni, SPSS uygulamalart ve yorum. Ankara: Pegem Akademi Yayınc1lı. 
Büyüköztürk, Ş., Çakmak, E. K., Akgün, Ö. E., Karadeniz, Ş. ve Demirel, F. (2014). Bilimsel araştırma yöntemleri. Ankara: Pegem Akademi Yayinc1lik.

Cakir, L. ve Kocabaş, I. (2016). Mentoring in gifted student's education and a model suggestion. Educational Process: International Journal, 5(1), 76-90.

Calabrese, R. L. ve Tucker-Ladd, P. R. (1991). The principal and assistant principal: A mentoring relationship. NASSP Bulletin, 75, 67-74.

Can, A. (2014). SPSS ile bilimsel araştırma sürecinde nicel veri analizi. Ankara: Pegem Akademi.

Chao, G. T. (2007). Mentoring and organizational socialization. B. R. Ragins ve E. K. Kram, (Ed.), The handbook of mentoring at work: Theory, research and practice içinde (179-196). Los Angeles: Sage Publications.

Dougherty, T. W. ve Dreher, G. F. (2007). Mentoring and career outcomes. B. R. Ragins ve E. K. Kram, (Ed.), The handbook of mentoring at work: Theory, research and practice içinde (51-93). Los Angeles: Sage Publications.

Dougherty, T. W., Turban, D. B. ve Haggard, D. L. (2007). Naturally occuring mentoring relationships involving workplace employees. T. D. Allen ve L. T. Eby, (Ed.), The Blackwell handbook of mentoring: A multiple perspectives approach içinde (139-158). Oxford: Blackwell Publishing Ltd.

Douglas, C. A. (1997). Formal mentoring programs in organizations: An annotated bibliography. North Carolina: Center for Creative Leadership.

Eby, L. T., Allen, T. D., Evans, S. C., Ng, T. ve DuBois, D. L. (2008). Does mentoring matter? A multidisciplinary meta-analysis comparing mentored and non-mentored individuals. Journal of Vocational Behavior, 72, 254-267. 
Educause. (b.t.). 19 Eylül 2015, http://www.educause.edu/careers/special-topic-programs/mentoring/a bout-mentoring/types-mentoring-functions

Ereş, F. (2009). Okul yöneticilerinin yetiştirilmesinde mentorlük. Kafkas Üniversitesi Sosyal Bilimler Enstitüsü Dergisi, 3, 157-165.

Fagenson-Eland, E. ve Lu, R. Y. (2004). Virtual mentoring. D. Clutterbuck, ve G. Lane, (Ed.), The situational mentor: An international review of competences and capabilities in mentoring içinde (148-159). Burlington: Gover Publishing.

Field, A. (2009). Discovering statistics using SPSS. Londra: Sage.

Garrido, L. E., Abad, F. J. ve Ponsoda, V. (2013). A new look at Horn's parallel analysis with ordinal variables. Psychological Methods, 18(4), 454-474.

Greenhaus, H. ve Singh, R. (2007). Mentoring and the work-family interface. B. R. Ragins, ve E. K. Kram, (Ed.), The handbook of mentoring at work: Theory, research and practice içinde (519-544). Los Angeles: Sage Publications.

Gündüz, B., Çapri, B. ve Gökçakan, Z. (2013). Mesleki tükenmişlik, işle bütünleşme ve iş doyumu arasındaki ilişkilerin incelenmesi. Eğitim Bilimleri Araştırmaları Dergisi, 3(1), 29-49.

Gürbüz, R., Erdem, E. ve Yıldırım, K. (2013). Başarılı okul müdürlerinin özellikleri. Dicle Üniversitesi Ziya Gökalp Eğitim Fakültesi Dergisi, 20, 167-179.

Haggard, D. L., Dougherty, T. W., Turban, D. B. ve Wilbanks, J. E. (2011). Who is a mentor? A review of evolving definitions and implications for research. Journal of Management, 37(1), 280-304.

Haines, S. T. (2003). The mentor-protégé relationship. American Journal of Phamaceutical Education, 67(3), 1-7. 
Hall, B. F. (2008). Job Satisfaction experienced by career assistant principals in the State of Georgia. Yayımlanmamış doktora tezi, Georgia Southern Üniversitesi.

Haynes, R. K. ve Ghosh, R. (2008). Mentoring and succession management: An evaluative approach to the strategic collaboration model. Review of Business, 28, 2-12.

Hobson, A. J. ve Malderez, A. (2013). Judgementoring and other threats to realizing the potential of school-based mentoring in teacher education. International Journal of Mentoring and Coaching in Education, 2(2), 89-108.

Hoe, S. L. (2008). Issues and procedures in adopting structural equation modeling technique. Journal of Applied Quantitative Methods, 3(1), 76-83.

Holtom, B. C., Mitchell, T. R., Lee, T. W. ve Eberly, M. B. (2008). Turnover and retention research: A glance at the past, a closer review of the present, and a venture into the future. The Academy of Management Annals, 2(1), 231-274.

Hough, L. M. ve Ones, D. S. (2005). The structure, measurement, validity, and use of personality variables in industrial, work, and organizational psychology. N. Anderson, D. S. Ones, H. K. Sinangil ve C. Viswesvaran, (Ed.), Handbook of industrial, work and organizational psychology (1): Personnel psychology içinde (233-277). Londra: Sage Publications.

Hu, L. ve Bentler, P. M. (1999). Cutoff criteria for fit indexes in covariance structure analysis: Conventional criteria versus new alternatives. Structural Equation Modeling, 6(1), 1-55.

Izadinia, M. (2016). Preservice teachers' professional identity development and the role of mentor teachers. International Journal of Mentoring and Coaching in Education, 5(2), 127-143. 
İbrahimoğlu, N. (2013). Biçimsel olmayan mentorluk yoluyla öz-etkinliğin artır1lmas1. Sosyoekonomi, 1, 141-156.

İbrahimoğlu, N., Uğurlu, Ö. Y. ve Kızıloğlu, M. (2011). Örgütlerde mentorlügün örgütsel güven algısına etkisine ilişkin bir araştırma. Ç.Ü. Sosyal Bilimler Enstitüsü Dergisi, 20(3), 297-318.

İstanbul İl Millî Eğitim Müdürlüğü (b.t.). 27 Kasım 2015, http://www.istanbul.meb.gov.tr

İşcan, Ö. F. ve Çakır, S. (2016). Mentorluk ve psikolojik güçlendirmenin öz yeterlilik algısına etkisi. Süleyman Demirel Üniversitesi Íktisadi ve İdari Bilimler Fakültesi Dergisi, 21(1), 1-15.

Jackson, D. L., Gillaspy, J. A. ve Purc-Stephenson, R. (2009). Reporting practices in confirmatory factor analysis: An overwiev and some recommendations. Psychological Methods, 14(1), 6-23.

Johnson, W. B. ve Ridley, C. R. (2004). The elements of mentoring. New York: Palgrave Macmillan.

Judge, T. A., Parker, S., Colbert, A. E., Heller, D. ve Ilies, R. (2001). Job satisfaction: A cross-cultural review. N. Anderson, D. S. Ones, H. K. Sinangil ve C. Viswesvaran, (Ed.), Handbook of industrial, work and organizational psychology(2): Organizational psychology içinde (25-52). Londra: Sage Publications.

Kahle-Piasecki, L. (2011). Mentoring: what organizations need to know to improve performance in the $21^{\text {st }}$ century workplace. Yayımlanmamış doktora tezi, Toledo Üniversitesi.

Karadağ, S. (2015). Eğitim kurumlarında mentorluk uygulamaları: Durum analizi. Yayımlanmamış yüksek lisans tezi, Bahçeşehir Üniversitesi.

Karaköse, T. ve Kocabaş, İ. (2009). An investigation of ethical culture in educational organizations. African Journal of Business Management, 3(10), 504-510. 
Karakuş, K. ve Tok, T. N. (2015). Okul yöneticilerinin uyguladıkları mentorluk fonksiyonları ile sınıf öğretmenlerinin iş doyumu arasındaki ilişki. EYFOR VI. Uluslararası Eğitim Yönetimi Forumu Özet Bildiri Kitabı. Uluslararası Kıbrıs Üniversitesi.

Karasar, N. (2014). Bilimsel araştırma yöntemleri. Ankara: Nobel Yayın Dăğtım.

Kennedy, S. L. (2013). Mentoring functions and job satisfaction of community college leaders. Yayımlanmamış doktora tezi, North Carolina State Üniversitesi.

Keser, A. (2005). İş doyumu ve yaşam doyumu ilişkisi. Çalışma ve Toplum, 4, 77-96.

Kim, J. (2011). The effect of mentoring in the public sector. The Korean Journal of Policy Studies, 26(1), 97-115.

Kim, S. E. (2014). The mentor-protégé affinity on mentoring outcomes: The mediating effect of developmental networking. International Review of Public Administration, 19(1), 91-106.

Kline, R. B. (2011). Principles and practice of structural equation modeling. New York: The Guilford Press.

Kocabaş, İ. ve Yirci, R. (2011). Öğretmen ve yönetici yetiştirmede mentorluk: Mentorluğun eğitim sisteminde kullanılması. Ankara: Anı Yayınc1lık.

Korkmaz, M. (2005). Okul yöneticilerinin yetiştirilmesi: Sorunlar-çözümler ve öneriler. Gazi Üniversitesi Gazi Eğitim Fakültesi Dergisi, 25(3), 237-252.

Kram, E. K. (1983). Phases of mentor relationship. Academy of Management Journal, 26, 608-625.

Kul, M. (2010). Okul yöneticilerinin liderlik stilleri ile beden eğitimi öğretmenlerinin yıldırma (mobbing) yaşama düzeyleri, örgütsel bağlllıkları 
ve iş doyumu arasındaki ilişski. Yayımlanmamış doktora tezi, Gazi Üniversitesi.

Lo, M., Ramayah, T. ve Kui, L. C. (2013). Mentoring and job satisfaction in Malaysia: A test on small medium enterprises in Malaysia. International Journal of Psychology: A Biopsychosocial Approach, 13, 69-90.

Locke, A. E. (1976). The nature and causes of job satisfaction. M. D. Dunnette, (Ed.), Handbook of industrial and organizational psychology içinde (1297-1349). Chicago: Rand McNally College Publishing Company.

Marquardt, M. J. ve Loan, P. (2006). The manager as mentor. Westport: Greenwood Publishing Group.

Millî Eğitim Bakanlığı (MEB). (2015). Millî Eğitim Bakanlı̆̆ı öğretmen atama ve yer değiştirme yönetmeliği.

Morrison, M. A. (2009). Do mentor and protégé personality interact to predict quality of mentoring? Yayımlanmamış yüksek lisans tezi, Georgia Üniversitesi.

Mukhtar, F. (2012). Work life balance and job satisfaction among faculty at Iowa State University. Yayımlanmamış doktora tezi, Iowa State Üniversitesi.

Noe, R. A. (1988). An investigation of the determinants of successful assigned mentoring relationships. Personnel Psychology, 41(3), 457-479.

Noe, R. A., Greenberger, D. B. ve Wang, S. (2002). Mentoring: what we know and where we might go. Research in Personnel and Human Resources Management, 21, 129-173.

O'Connor, B. P. (2000). SPSS and SAS programs for determining the number of components using parallel analysis and Velicer's MAP test. 
Behavior Research Methods, Instruments \& Computers, 32(3), 396-402.

Orland-Barak, L. (2014). Mediation in mentoring: a synthesis of studies in teaching and teacher education. Teaching and Teacher Education, 44, 180-188.

Özcan, K. ve Çağlar, Ç. (2013). İl eğitim denetmenlerinin mesleki gelişiminde mentorluk. Adlyaman Üniversitesi Sosyal Bilimler Enstitüsü Dergisi, 6(13), 177-204.

Özdemir, T. Y. (2012). Il eğitim denetmen ve yardımcılarının mesleki gelişimlerini devam ettirmede e-mentorluk modeli. Yayımlanmamış doktora tezi, Firat Üniversitesi.

Özdemir, T. Y. ve Boydak-Özkan, M. (2013). E-mentorluk sürecinin mente başarısına etkisi. Bartın Üniversitesi Eğitim Fakültesi Dergisi, 2(1), 170-186.

Özkalp, E. ve Kırel, Ç. (2013). Örgütsel davranış. Bursa: Ekin Yayınevi.

Özkalp, E., Kırel, Ç., Sungur, Z. ve Cengiz, A. A. (2006). Örgütsel toplumsallaşma sürecinde mentorluk ve mentor'un yeri ve önemi: Anadolu Üniversitesi araştırma görevlileri üzerine bir inceleme. Anadolu Üniversitesi Sosyal Bilimler Dergisi, 6(2), 55-69.

Paskey, R. J. (1989). The principal as mentor, partner of assistant principals. NASSP Bulletin, 73, 95-98.

Pfeffer, J. (1994). Competitive advantage through people: Unleashing the power of the work force. Massachusets: Harvard Business School Press.

Ragins, B. R. ve Cotton, J. L. (1999). Mentor functions and outcomes: a comparison of men and women in formal and informal mentoring relationships. Journal of Applied Psychology, 84(4), 529-550.

Ragins, B. R. ve Kram, E. K. (2007). The roots and meaning of mentoring. B. R. Ragins, ve E. K. Kram, (Ed.), The handbook of mentoring at 
work: Theory, research and practice içinde (3-15). Los Angeles: Sage Publications.

Recepoğlu, E. ve Kılınç A. Ç. (2014). Türkiye'de okul yöneticilerinin seçilmesi ve yetiştirilmesi, mevcut sorunlar ve çözüm önerileri. International Periodical for the Languages, Literature and History of Turkish or Turkic, 9(2), 1817-1845.

Robbins, S. P. (2003). Essentials of organizational behavior. New Jersey: Prentice Hall.

Sandybayev, A. ve Erdem, O. (2015). A strategic approach to mentoring in organizations: A case study on athletic clubs. International Journal of Advanced Research in Science, Engineering and Technology, 2(5), 632-639.

Scandura, T. A. (1992). Mentorship and career mobility: An empirical investigation. Journal of Organizational Behavior, 13(2), 169-174.

Scandura, T. ve Pellegrini, E. K. (2004). Competences of building the developmental relationship. D. Clutterbuck, ve G. Lane, (Ed.), The situational mentor: An international review of competences and capabilities in mentoring içinde (83-93). Burlington: Gower.

Schermelleh-Engel, K., Moosbrugger, H. ve Müller, H. (2003). Evaluating the fit of structural equation models: Tests of significance and descriptive goodness-of fit measures. Methods of Psychological Research Online, 8(2), 23-74.

Schreiber, J. B., Nora, A., Stage, F. K., Barlow, E. A. ve King, J. (2006). Reporting structural equation modeling and confirmatory factor analysis results: A review. The Journal of Educational Research, 99(6), 323-337.

Schmitt, T. A. (2011). Current methodological considerations in exploratory and confirmatory factor analysis. Journal of Psychoeducational Assessment, 29(4), 304-321. 
Sezgin, F., Koşar, S. ve Er, E. (2014). Okul yöneticisi ve öğretmen yetiştirmede mentörlük sürecinin incelenmesi. Kastamonu Eğitim Dergisi, 22(3), 1337-1356.

Shea, G. F. (2002). Mentoring: How to develop successful mentor behaviors. California: Crisp Publications.

Slocum-Gori, S. L. ve Zumbo, B. D. (2011). Assesing the unidimensionality of psychological scales: Using multiple criteria from factor analysis. Social Indicators Research, 102, 443-461.

Spector, P. E. (1997). Job satisfaction: Application, assessment, causes and consequences. California: Sage Publications, Inc.

Stone, F. (2002). Coaching and mentoring. Oxford: Capstone Publishing.

Şerefhanoğlu, O. (2014). Okul müdürlerinin mentorluk fonksiyonlart ile ögretmenlerin örgütsel uyum düzeyleri arasındaki ilişki: Balıkesir örneği. Yayımlanmamış yüksek lisans tezi, Balıkesir Üniversitesi.

Tabachnick, B. G. ve Fidell, L. S. (2013). Using multivariate statistics. Boston: Pearson.

Thompson, B. (2004). Exploratory and confirmatory factor analysis: Understanding concepts and applications. Washington: American Psychological Association.

Türk Dil Kurumu Büyük Türkçe Sözlük. (b.t.). 1 Kasım 2015, http://www.tdk.gov.tr/index.php?option=com_bts

Walker, A. ve Stott, K. (2004). Preparing for leadership in schools: the mentoring contribution. B. J. Caldwell ve E. M. Carter, (Ed.), The return of the mentor: Strategies for workplace learning içinde (77-90). Londra: The Falmer Press.

Wallace, S. ve Gravells, J. (2008). Professional development in the lifelong learning sector: Mentoring. Exeter: Learning Matters. 
Weiss, D. J., Davis, R. V., England, G. W. ve Lofquist, L. H. (1967). Manual for the Minnesota satisfaction questionnaire (22). Minnesota Studies in Vocational Rehabilitation, Minneapolis: University of Minnesota, Industrial Relations Center.

Williams, B., Onsman, A. ve Brown, T. (2010). Exploratory factor analysis: A five-step guide for novices. Journal of Emergency Primary Health Care, 8(3), 1-13.

Yavuz, G. ve Doğan, N. (2015). Boyut sayısı belirlemede Velicer'in map testi ve Horn'un paralel analizinin kullanılması. Hacettepe Üniversitesi Eğitim Fakültesi Dergisi, 30(3), 176-188.

Y1lmaz, K. (2009). Okul müdürlerinin denetim görevi. İnönü Üniversitesi Eğitim Fakültesi Dergisi, 10(1), 19-35.

Yirci, R. (2009). Mentorluğun eğitimde kullanılmast ve okul yöneticisi yetiştirmede yeni bir model önerisi. Yayımlanmamış yüksek lisans tezi, Frrat Üniversitesi.

Yirci, R. ve Kocabaş, İ. (2010). The importance of mentoring for school principals: A conceptual analysis. International Journal of Educational Leadership Preparation, 5(2), 1-7.

Yirci, R. ve Kocabaş, İ. (2012). Türkiye'de bir mentorluk uygulaması: Aday öğretmenlerin yetiştirilmesi. R. Yirci ve İ. Kocabaş, (Ed.), Dünyada mentorluk uygulamaları içinde (115-132). Ankara: Pegem Akademi.

Yirci, R., Özdemir, T. Y., Kartal, S. E., Kocabaş, İ. ve Aksu, C. N. (2015). Müdür yardımcılarının yetişmesinde okul müdürlerinin mentorluk rolleri: Sorunlar ve çözüm önerileri. 10. Ulusal Eğitim Yönetimi Kongresi Bildiri Özetleri Kitabı. Gaziantep Üniversitesi.

Yuan, E. R. (2016). The dark side of mentoring on pre-service language teachers' identity formation. Teaching and Teacher Education, 55, 188-197. 